\title{
159 介在物を有する回転円板におけるき裂先端の実験解析
}

Experiment Analysis at Crack Tip in Rotation Disk Having Intervention Thing 正 江角 剓 (芝浦工大) 準 西村 健太郎((株)トランストロン) ○学 杉村 樹之(芝浦工大)

Ezumi TUTOMU, Shibaura Institute of Technology

Kentarou NISIMURA, Transtron Co.,Ltd

Shigeyuki SUGIMURA, Shibaura Institute of Technology

Key Words : Rotating Disk, Insert, Stress Intensity Factor, Photoelasticity, Caustics Method

\section{1. 粕亩}

機械が安全に稼動するためには，使用条件や環境，または 材料自身の強度などに基づく設計が必要不可欠である.また 使用環境は過酷さを增し、今まで以上に高い信頼性か㴗求さ れる. 大型の構造物は，その製造過程中に部材内のき翌の潜 在の可能性を大にし，過酷な使用条件での使用となるためき 裂の発生頻度を高める結果となる. さらに材料の柽量化また は形状の奻率化を余儀なくされ，安全性と経清性との略和の とれた設計をしなければならない。

なかでも回転機械の種類は広篹囲にわたっており，これら 回転体の応力解析や安全性の確保は，ますます重要になって くる. 今日では，このようなき裂先端の实験応力解析の報告 はいくつかみられる.

譏械や構造物の破壊は，介在物による応力集中や破壊が起 因になることが多い，介在物とき挔の干涉問題は，材料の破 燷現象の研究に対して重要である.この問題についてこれま で多くの解析が行われている(1)(2)(3)がシミュレーション解析 が主流である.

以上のような状況にかんがみ，本研究では，介在物がき翌 先端の応力拡大俰数に及ほすす影整を光弾性応力凍結法およひ コースティックス法により英磁解析を行い検时した。

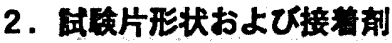

Fig.1 に研硢片形状と寸法を示す. 供試材はアラルタイトB (CT200)と硬化削(HT901)を重量比 $100: 30$ で配合した厚さ 6 $\mathrm{mm}$ のエポキシ樹脂板である. 直径 $132 \mathrm{~mm}$ のビッチ円周上（縒 硢片中心から外径までの $60 \%$ の位置）に，介在物を挿入する 為, 直径 $20 \mathrm{~mm}$ の円孔を 4 筒所空けた. き裂加工には厚さ $0.15 \mathrm{~mm}$ の極細目のこ刃を使用し，半径方向に介在物（円孔） からき裂先端までの距離が $2,4,6 \mathrm{~mm}$ となるように, 中心 側と円周側それそれに挿入した. なお，き糸長さはすへてて 2a $=10 \mathrm{~mm}$ 一定とした. 介在物にはアラルダイト B (CT200) と 硬化敖（HT901）を重量比 100:20, 100:25，100:40 のエポキ シ捌脂とし，円孔との接着には常温硬化型のエポキシ掛脂 （KR-351 透明, テレコファイン）によるはめ込みを用いた. 凍拮温度による回転円板の光弾性感度は $3.34 \mathrm{~mm} / \mathrm{N}$ である。
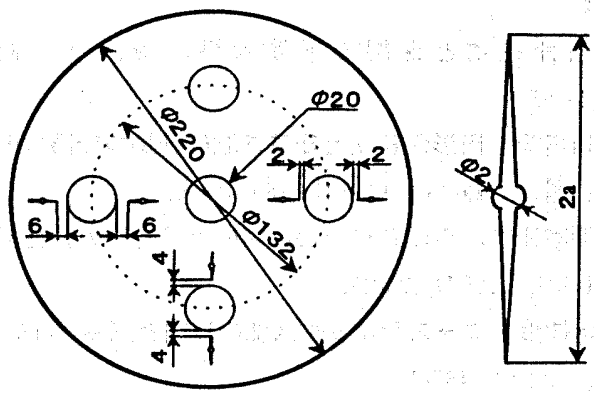

Fig.1 Shape and dimension of specimen

\section{3. 英硢方法}

本実験では, Fig.2 に示すようなエポキシ樹脂の応力東結サ

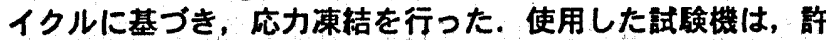
容回転数 5500rpm までの無段变速回転試硢機で，炉外から回 転を伝えるようになっている. 本実筁の回転中の応力凍結は， 回枟数一定の定常状態における応力東結である。回轱数 $1600 \mathrm{rpm}$ で炉内温度を最初の 2 時間で常温から $125^{\circ} \mathrm{C}$ に上げ 4 時間保持し，その後 $3^{\circ} \mathrm{C} / \mathrm{h}$ の温度降下により室温まで下げ全 体で 36 時間かけて東蛣を完了する。

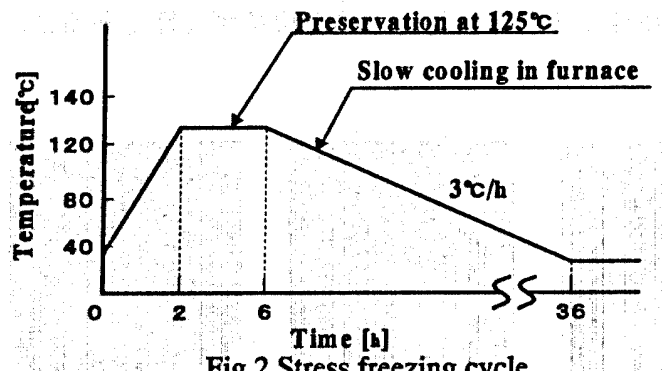

Fig.2 Stress freezing cycle

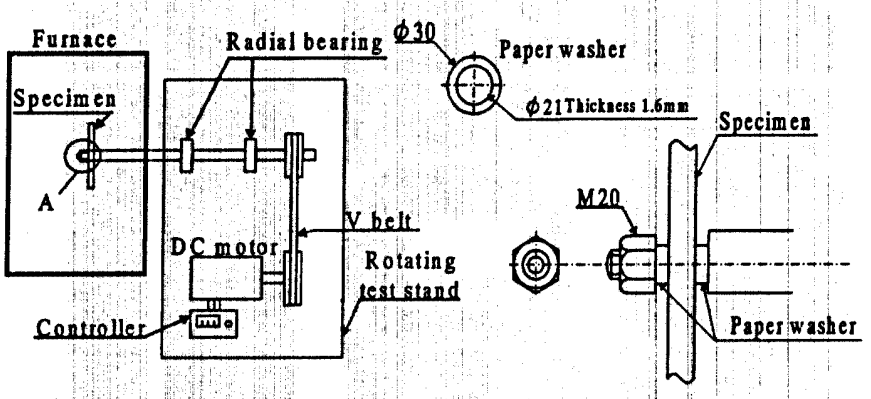

(a) Layout of experiment system

(b) Detail of A

Fig.3 Schematic illustration equipment for experiment

\section{4. 応力搪大係数の算定}

4. 1 光弾性法

回転丹板の光弾性法による応力拡大係数 $K_{\mathrm{I}}$ は, 式(1)で表す ことができる。ここで, $N$ はしま次数， $\alpha$ は光弾性感度， $t$ は䲽験片の厚さである.

$$
K_{\mathrm{I}}=\frac{N\left(2 \pi r_{m}\right)^{1 / 2}}{\alpha t \sin \theta_{m}}
$$

4. 2 コースティックス法

コースティックス法に用いる光学系を Fig.4に示す. 本实硂 は透過形により発散光を用いたもので, 光源に発振出力 $5 \mathrm{~mW}$ の He-Ne カスレーザーを用いた. コースティックス法による 応力拡大係数 $K_{r}$ は式(2)で与えられる(4).

$$
K_{r}=\left(1.671 / z_{o} t \mid c_{o}\right) \times\left(1 / \lambda^{3 / 2}\right) \times(D / 3.16)^{5 / 2}
$$




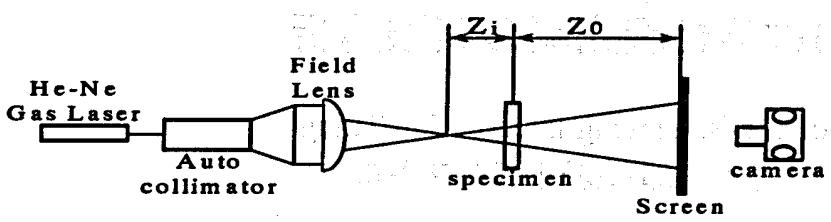

Fig.4 Schematic diagram of the experimental setup

\section{5. 实臤桔果およひ考整}

Fig.5 に応力東桔を行った試験片の等色楾しまルーブお よびコースティック像の一例を示す. Table. 1 に超音波法によ り求めた試験片およひ各介在物のヤング率を示す. (a)(b)(c) は介在物からき翌先端までの距離がそれぞ $2 \mathrm{~mm}, 4 \mathrm{~mm}$, 6mm のものである. コースティック像は (a) のようにき翏先 端が介在物に近いと，像が介在物本体から発生した像と干涉 する為，像がやや鮮明ではないが，すべてのパターンでほほ 真円であった. また等色線しまループもき翌に対して対称に しまが出ていることから、モード川による变形はほとんどな いと考えられる. よって本実験では $K_{1}$ 値のみを求めた. 写真 は介在物がラルタイト B と硬化敖の重量比 100:25のもので あるか，等色線しまループが介在物にまで進展している.こ れより試験片本体と介在物との接着状態が良好であることか 分った.

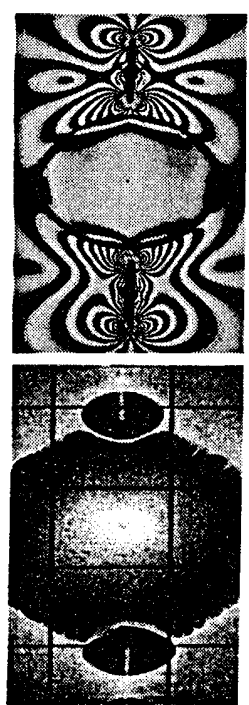

(a) $2 \mathrm{~mm}$
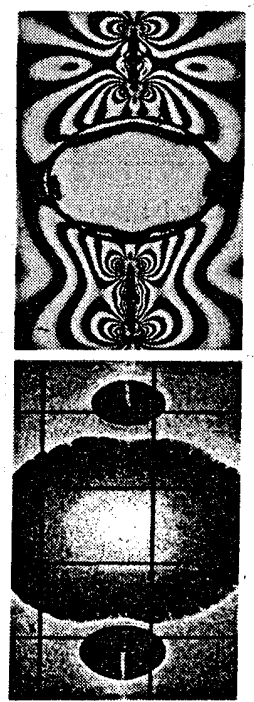

(b ) $4 \mathrm{~mm}$
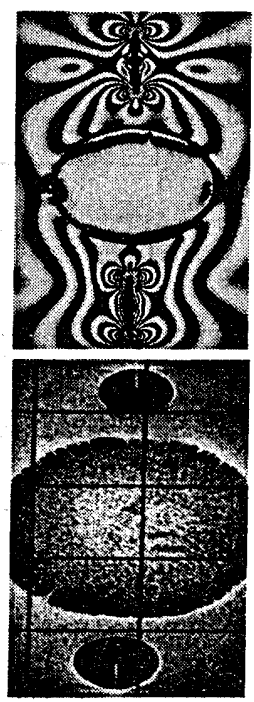

(c) $6 \mathrm{~mm}$
Fig.5 Photographs of isochromatic fringe and Caustic image pattern (100:25)

Table1 Young's modulus of Specimen and

\begin{tabular}{|c|c|c|c|c|}
\hline Weight ratio & $100: 20$ & $100: 25$ & $100: 40$ & Specimen \\
\hline Young's modulus (GPa) & 3.86 & 3.93 & 4.26 & 3.67 \\
\hline
\end{tabular}

光弾性法により得られたき裂先端から㐫力拡大係数 $K_{I}$ と介 在物境界からき翌先端までの距離の関係を円周側(OUT)は Fig.6に，中心側（IN）は Fig.7に示した. 同様にコースティ ックス法により得られた $K_{\mathrm{r}}$ と距離の関係を Fig.8, 9 に示した. 光弾性法とコースティックス法を比べると数值に量いがある もものほほ同じ傾向を示した. 円周側，中心側とも介在物境 界からき翌先端までの距離が大きくなるにつれ，全体的に $K_{\mathrm{r}}$ は小さい值を示した. き翌先端から介在物境界までの距離が 近い場合,アラルダイト B と硬化剛の重量比が 100:20, 100:25, 100:40の順に $K_{1}$ は大きい値を示したか, 離れるとほとんど差
が見られなかった. これはヤング率が大きい順に介在物本体 に応力集中が大きく、き翌先端の応力が楥和されたのではな いかと考えられる. また距離が離れると介在物がき翌先端に 与える㣏譬はほとんど無くなると考えられる. 円周側, 中心 側のき挔を比べると中心側のき翌の方が若干 $K_{1}$ は大きい傾 向を示した。:これは回転円板の遗心力が介在物境界に影整を 及ほした為と考えられる。

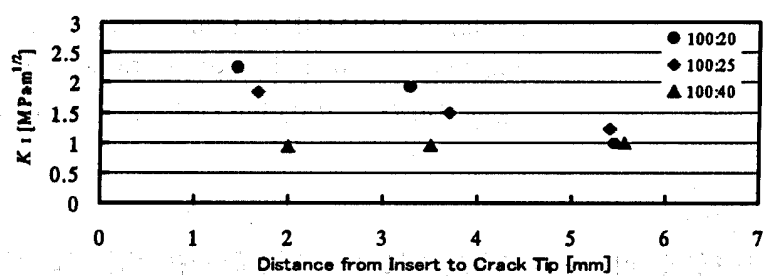

Fig. 6 $K$ I on photoelastic method

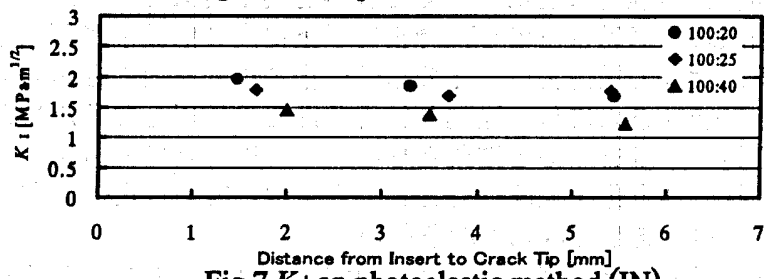

Fig. $7 \mathrm{~K}$ I on photoelastic method (IN)

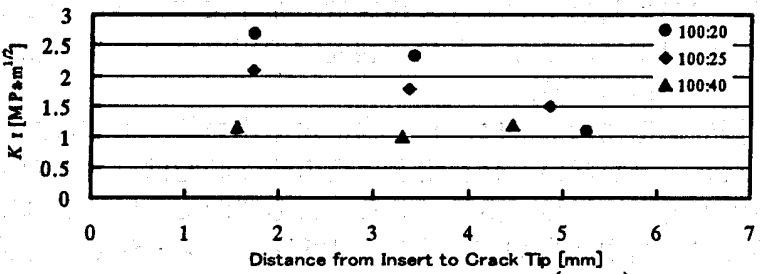

Fig. $8 \mathrm{~K}$ । on caustic method (OUT)

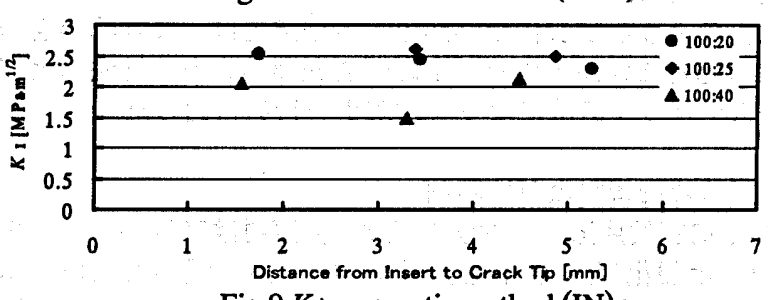

Fig. $9 \mathrm{~K}$ । on caustic method (IN)

\section{6. 结䡒}

本研究では回転円板中の介材物がき翌先端の応力拡大係数 $K_{\mathrm{r}}$ 值に及ほす影㸷を，光弾性法とコースティックス法により 検討した. その結果以下の知見か得られた。

1. 介在物境界からき糸先端までの距離が大きくなるにつれ, き翌先端の応力拡大係数 $K_{\mathrm{r}}$ は小さい值を示した.

2. き翌先端が介在物境界までの距離が近い場合, アラルタ イトB と硬化冎董量比 $100: 20 ， 100: 25 ， 100: 40$ の 順に $K_{r}$ は大きい値を示した。

\section{7. 考文献}

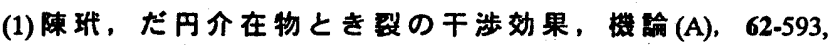
(1996-1)，49-55.

(2)石田畋・野口博司，円形介在物と任意き群群を持つ無限体の面内 荷重問題，譏铪(A), 49-438，(1983），1885-1890.

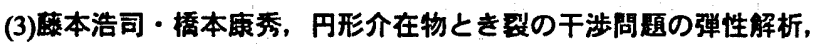
機踰(A), 61-581, (1995),20-27.

(4)高橋草・清水㑊治，コースティックス法の理論と適用例(1)，譏械 の研究,37-4, (1985) ,485-490. 